\title{
Multi-sited research methodology: Improving understanding of transnational concepts
}

\author{
Maaret Jokela-Pansini \\ Institute of Geography, Cultural Geography Research Unit, University of Bern
}

\begin{abstract}
Research at multiple sites and 'talking across worlds' have generally been important in feminist and geographic scholarship. Some studies have examined methodological dilemmas endemic to research involving multiple locations. Other studies have drawn on multi-sited research including perspectives of participants and researchers beyond a single site. Most of these studies have explored how groups, individuals, and discourses move between local and transnational spaces. However, evidence on how such methodologies improve our understanding of transnational concepts is still scarce. This article draws on two research projects on women's human rights activism in Honduras and South Africa and explores how multi-sited research improved the understanding of 'women human rights defenders.' In Honduras, activists in various women's groups have identified themselves as women human rights defenders since the coup d'état in 2009. This identity enabled them to integrate women's rights into a broader international human rights agenda. In South Africa, activists mostly use the term to influence decision-making at international organisations and to build alliances with activists globally. This multi-sited research reveals that women's human rights concepts are not 'given'. Rather, activists' lived experiences on multiple scales shape the way they understand and 'translate' such concepts.
\end{abstract}

Keywords: feminist methodology; multi-sited research; human rights; transnational concepts, Honduras, South Africa

\section{Introduction}

In recent years, geographic and feminist scholars have discussed different ways of 'talking across worlds' (Staeheli \& Nagar 2002). Some of these studies have reflected on the researcher's positionality in the field (Caretta \& Riaño 2016; Faria \& Mollett 2016; Schurr \& Segebart 2012) and in the academy (Pratt 2002; Raju 2002). Some have criticised how geographic studies still reproduce colonial ways of knowing and enacting universalising 
claims, despite reflective approaches in fieldwork (Sundberg 2014). Other studies, however, have called for multicultural approaches in research. They have claimed that researchers need to be cautious about essentialist contrasts between 'Western' and 'Third World' cultures (Narayan \& Harding 2000; Mohanty 2003; Manea 2016). A common aim of such contributions has been to understand research from different perspectives. Such 'multidirectional transfers' have become central for knowledge production (Segebart \& WastlWalter 2012). One such approach is multi-sited research, which generally studies social phenomena that one single site cannot sufficiently explain (Falzon 2016; Marcus 1995; Marcus 2009; Walker 2015; Collins \& Huang 2012 in this journal).

However, most studies exploring how different actors shape research have focused on questions of power, representation, and positionality. Only few have analysed how such approaches help conceptualise research (Monk et al. 2003; Pratt \& Johnston 2014). Multisited approaches mostly investigate how actors move between spaces but rarely study how transnational concepts such as human rights are understood in different places. Understanding such women's human rights concepts is important because for a decade, women activists from urban and rural areas worldwide have been framing their activism as 'women human rights defenders'. Scholars, including Fraser (2013), argue that women have found new ways to respond to multilevel socioeconomic and political crises in the $21^{\text {st }}$ century. I argue that 'women human rights defenders' is one of these ways.

This paper analyses how research participants and collaborators at multiple sites improved the understanding of the concept 'women human rights defenders'. I contend that this approach revealed questions that would have remained invisible by examining one case study. Multi-sited research, similar to human geographic research, regards space as socially constructed. Hence, this study understands research as a relational practice that researchers and participants mutually construct (Okazawa-Rey 2009; Massey 1999; Demeritt \& Dyer 2002). Such understanding of space replaces fixed categories such as location with the language of flows and fluidity (Marston, Jones, \& Woodward, 2005). Researchers, collaborators and participants construct spaces 'in between' in an ongoing reflexive process (Katz, 1992, 502).

Two projects illustrate this understanding, my research about women human rights defenders in Honduras and a collaborative research on women's human rights activism in South Africa. Empirical evidence revealed how activists perceived 'women human rights defenders' as an identity and an advocacy tool on different scales. In Honduras, activists in feminist and women's groups from urban and rural areas have identified themselves as 
women human rights defenders since protests against the coup d'état in 2009. As women human rights defenders, activists integrated women's rights issues into a broader human rights agenda. In South Africa, activists 'translated' the concept through transnational networks into the local context. They mostly perceived 'women human rights defenders' as a term to use to advocate their position in international contexts, both in order to influence decision-making at international organisations such as the $\mathrm{UN}$, and as a way to build alliances with activists globally.

\section{Multi-sited research: a methodology to study transnational concepts}

Research involving multiple sites has been subject to much methodological analysis in feminist and human geographic scholarship (Fisher 2015; Nagar 2014; Staeheli \& Nagar 2002). Scholars have long sought to understand knowledge situated between various geographic and cultural contexts and to 'disentangle processes of interpretation, translation, stuttering and the partly understood' (Haraway 1991, 195). However, some have criticised how even reflective research methodology still produces colonial ways of knowing. Consequently, they have urged scholars to 'decolonise' research processes (Smith 2012; Mendoza 2002; Sundberg 2014).

Multi-sited research is an ethnographic methodology (Marcus, 2009; 1995) and assumes that researchers move through a spatially dispersed field (Falzon 2016); in other words, they follow people, connections and relationships across space. Multi-sited research thus 'moves out from the single sites and local situations of conventional ethnographic research designs to examine the circulation of cultural meanings, objects, and identities in diffuse time-space' (Marcus 1995, 96). The approach seeks to reduce hierarchies and decentralise research both geographically and spatially (Falzon 2016).

Research at multiple sites is crucial particularly for understanding how discourse moves between spaces. Thayer (2010) found in her research on Brazilian rural women's organisations that 'translations' of a specific discourse, or refusals to translate, play a strategic role for activists and represent a significant form of political agency. Activists' lived experiences are important for such 'translations' because these experiences shape their views, interests, and identities. In addition, human rights concepts are not set but rather constitute different meanings when they travel between local, regional and transnational spaces (Nagar \& Ali 2003). 
This study focuses on opportunities for multi-sited methodology to understand transnational concepts rather than explaining why activists understood 'women human rights defenders' in a certain way. However, some reflections on how transnational concepts, including human rights, move between spaces are important to understand how activists in Honduras, South Africa and other world regions have embraced the term 'women human rights defenders.' Merry (2006a, 221) has stated that

to be accepted, they [human rights] have to be tailored to the local context and resonate with the local cultural framework. ... they must emphasize individualism, autonomy, choice, bodily integrity, and equality - ideas embedded in the legal documents that constitute human rights law.

Feminist and women's organisations have acknowledged that transnational alliances are crucial for working against neoliberal markets and for gender and social justice (Thayer 2010; Mohanty 2013). I argue that women human rights defenders can be seen as one such alliance: Thousands of activists worldwide identify themselves as women human rights defenders (IM Defensoras 2013). Other scholars have emphasised the strategic value of such frameworks and stated these allow activists 'to contain and control' the system and enhance community wellbeing (Katz, 2012, 631).

Finally, as Okazawa-Rey (2009) reminds us, language is key for understanding concepts, including human rights. Along with its cultural context, language is 'always something to be negotiated, not to be taken for granted, and not to be assumed'. She reflects on her work with Arabic- and English-speaking activists in Palestine: 'We could not rely on taken-for-granted understandings, but had to define and build consensus around the words we used.' I build on this extensive feminist, human geographic and ethnographic work, which emphasises reflecting on various geographic and cultural contexts and on movements of discourses between various scales when investigating transnational concepts.

\section{Studying women human rights defenders in Honduras and South Africa}

Merry (2006) has stated that various intermediaries help translate human rights, including local activists, human rights lawyers, feminist NGO leaders, academics, who have one foot in the transnational community and one at home. In the past few years, my research has focused on such actors, particularly the National Network of Women Human Rights Defenders in Honduras. I worked in a feminist organisation in 2008-2009 in Tegucigalpa. For four months in 2013, I conducted semi-structured interviews, focus group discussions and participant observation in Tegucigalpa, San Pedro Sula, and La Esperanza with 30 women activists. In 
2014-2016, informal conversations with numerous activists at UN meetings in Geneva, Switzerland, deepened my understanding of instruments, discourses and networks around women's human rights activism.

In addition to my research in Honduras, I studied women's human rights activism in South Africa as part of a joint research project Safeguarding Democracy. Contests of Values and Interests between universities in South Africa and Switzerland. Firstly, the project's aim was to gain a 'crossed gaze' (regard croisé) on our individual research projects. Researchers of the project's first phase coined this term in 2010. In our gender working group, researchers based at Swiss universities conducted fieldwork in South Africa and South African project members studied women's human rights discourses in Switzerland. Thus, this paper should be read as part of a larger project, which includes other 'crossed gazes'.

Secondly, the aim was to explore how to break patterns of northern dominance in research projects. This approach is in line with feminist postcolonial theories including standpoint and intersectional theories highlighting the diversity of women's experience (Mohanty 2003; Crenshaw 1991). It draws on numerous scholars' criticism of essentialist gender and cultural categories assuming that 'women' have a coherent group identity within different cultures (Narayan and Harding 2000; Mohanty 2003). These studies suggest that gender essentialism constructs sharp binaries about the qualities, abilities, and locations of 'men' and 'women' while cultural essentialism constructs sharp binaries between 'Western culture' and 'Non-western cultures' or 'other' cultures.

Thirdly, as Katz notes, '[e]ven in a universe decentred and in flux, we are situated and bear responsibility for interrogating our positionings' (Katz, 1992, 504). Part of such interrogation is to acknowledge how multi-sited research comprises researchers and activists who are intermediaries of human rights discourse (Merry 2006). In this paper, I seek to present researchers' and participants' views and at the same time, acknowledge that my understanding has been as influenced by my location and identity as any of the participants I studied (Mama 2011; Naples 2003). Some participants in South Africa were familiar with women human rights defenders but others learned about the term through our conversations. In my role as intermediary, I 'translated' to activists in South Africa what I had learned from Honduran activists or from international organisations. Thus, a 'crossed gaze' goes beyond mere self-reflection and encourages us to include both participants' and researchers' gaze outside the case study into the analytical process (Meintjes and Scheidegger 2013).

This approach aligns with Hancock's alternative of non-binary categories (Hancock, 2016, 82): 
' $[\ldots]$ Conceptualising reality in a way that takes the politics of subaltern communities as seriously as the politics of mainstream society means that one can no longer selflocate as either on a margin or in a centre.

During three visits in 2015 and 2016, a total period of two months, I engaged in participant observation and conducted interviews and focus-group discussions with activists, individual scholars, and women from seven human rights- and women's organisations in Johannesburg and Cape Town. I consciously sought a 'speaking-with approach' (Nagar 2014; De Vault 1999). According to Nagar $(2014,120)$, such an approach provides 'concrete spaces to envision ways in which feminist scholars ... might conceptualise accountability to people's struggles for self-representation and self-determination' and aims to flatten the power relations between the interviewer and interviewee. We discussed perceptions of both the notion 'women human rights defenders' and also challenges to women's rights and the ways activists sought to respond to these challenges in South Africa and other countries. Like the participants, South African research collaborators enabled me to reflect on the concepts I used.

This article does not claim that all women activists in Honduras or in South Africa embrace this activist identity but rather acknowledges that some might have different views. For example, four of the other organisations I interviewed were not familiar with the term or framed their activism differently. 'Activists' or 'participants' in this article therefore refers to the women of these specific networks and organisations - Just Associates International (JASS), The Association for Progressive Communications Women's Rights Programme (APC WRP) and the Centre for Applied Legal Studies (CALS) - which are composed of women from various ages, races, ethnicities, sexual orientations, and socioeconomic backgrounds.

\section{Defensoras de derechos humanos: Women Human Rights Defenders in Honduras}

The term 'human rights defenders' originates in the UN Declaration on Human Rights Defenders (1998). In 2010, the UN recognised that women defending human rights face gender-specific threats and violence (UNHRC 2012). Since then, women human rights defenders refer to women who individually or together act in defence of women's human rights as well as the full range of rights, whether civil, political, economic, social, cultural, environmental, sexual, or reproductive (IM Defensoras 2015). 
In the late $20^{\text {th }}$ century, many women's and feminist movements across Latin America organised in human rights organisations, adopted the international slogan 'women's rights are human rights' and contributed to the mainstreaming of women's rights in government institutions (Jaquette 2009; Alvarez 2000). However, most activists from the National Network of Women Human Rights Defenders in Honduras began identifying themselves as women human rights defenders due to the protests against the coup in 2009 (see also [citation removed]). The national network emerged after a regional meeting with Central American women human rights activists in Mexico in 2010.

Recently in Honduras, militarisation and political instability have often been the ground for repression against women human rights defenders (IM-Defensoras 2013). In addition, rural communities, most of them indigenous or Afro-descendant Garifuna, have lost their lands because the state is privatising communal and state-owned property and selling it to international investors (Brondo 2013; Mollett 2016).

A woman human rights lawyer explained how the concept of women human rights defenders spread after the political upheaval in 2009:

Before, it [human rights defender] was a job. When someone knew of human rights violations, he/she searched for people who worked in organisations. Now the same people are capable of making announcements, calling the radio and documenting human rights violations. [After the coup] many people documented what happened in their communities and brought the documentations to us. Now there are lawyers' networks, of environmental lawyers, of women defenders, of various sectors. So, it was a mere necessity.

This lived experience of the activist after the coup shows how defending human rights reflected activists' strategies to seek justice and to organise with others. They used an international concept but embraced it as a local identity, as defensoras. It shows that understanding how women themselves define their activism is important because such definitions can challenge international organisations' assumptions (Nagar, 2014).

When I asked members of the National Network of Women Human Rights Defenders, what being women human rights defenders meant for them, many associated the identity with feelings of pride and responsibility. Merary, a feminist student activist, explained: 'First of all, it means pride. That we can protect people's lives; it is very gratifying to know we can do something.' Carmen added, 'to be a woman human rights defender means to be on the side of law. It means a responsibility.' Martha, from a rural women's network, said, 'I have always been a human rights defender, for 30 years. But with the network, I began identifying myself 
as one'. In addition, their identity construction reflected transnational discourses on women human rights defenders, which promote self-care and feminist popular education as part of protecting activists (Jokela-Pansini 2016). These discourses emphasise the need for defending other women human rights defenders but also of taking care of one's own body and wellbeing (IM Defensoras 2013).

The women interviewed had experienced the concept as a strategy and advocacy tool on multiple scales besides being an identity. Locally, the interviewees felt the network protected them and raised their visibility in local communities. Internationally, as women human rights defenders, activists participated in human-rights delegations at the United Nations or the Inter-American Court of Human Rights. In joint submissions, they included gender-specific concerns into a broader human-rights agenda (UNHRC 2015). This part of the study shows how human rights concepts hold discursive power for feminists and other women activists in specific contexts.

\section{'Crossed gaze': Women organising for women's human rights in South Africa}

In South Africa, a growing number of organisations has adopted the concept 'women human rights defenders,' including the Association for Progressive Communications, the Women's Rights Programme (APC WRP), Just Associates International (JASS) and Centre for Applied Legal Studies (CALS). During my fieldwork in 2015, some participants explained that 'women human rights defenders' was still a rare concept in South Africa. Jenny from APC WRP stated,

I think the term, at least as a South African, is a pretty new one. In the anti-apartheid movement and in different feminist and sexuality rights movements, we never really defined ourselves as human rights defenders. If I think about the coalition [WHRDIC], there aren't many organisations from South Africa.

Maggie, coordinator of JASS Southern Africa explained how the concept in Southern Africa was different from other world regions: '[Regionally], it doesn't have the same currency as it has in Mesoamerica ... that it is empowering for women to define themselves as defenders.' Some argued that organisations saw the human rights language coming from donors. These statements reflect how lived experiences shape actors' identities, interests and views (Nagar \& Ali 2003). Another activist stated: 
Our entry point has been women's lived experiences in terms of their bodies and feminist popular education.[...] about how do you think about self-care in political ways.

Particularly those working in local communities explained they framed their activism around bodily integrity as self-care, well-being and safety, rather than defending human rights. Hence, in South Africa, the entry point was self-care and women's bodies. This was similar to transnational discourses on women human rights defenders and the statements of activists in Honduras.

Maggie stated, 'We are trying to find entry points to bring that discourse [women human rights defenders] alive but in a way that it's in the context.' Jenny noted that many called themselves feminists or women's rights activists although the activism or work they did was the same as women human rights defenders in other world regions. The statement confirms Merry's (2006) notion that activists 'translate' human rights discourses into local contexts in different ways. These conversations broke the fixed understanding I initially had of women human rights defenders through my fieldwork in Honduras. Activists saw that women human rights defenders enabled human rights issues to be addressed particularly in transnational contexts. They translated parts of the discourse into the local context, particularly those on bodily integrity (Merry 2006).

Some explained that locally, women activists could better relate to women human rights defenders than to feminism because the connotation of the latter was often Western or European. Scholars including Mama (2011) have argued that diverse colonial rules, political regimes and international development discourses have shaped the various manifestations of feminism in African contexts. Consequently, many mobilise women's rights in government institutions, international agencies, political parties and movements but distance themselves from feminist movements (see also Hassim 2006). Hence, locally, South African activists translated 'women human rights defenders' in certain contexts. As Jenny noted, 'Women human rights defenders' is a very strong label, even the word itself.'

Many related their activism to struggles against neoliberal politics, which is in line with Fraser's (2013) assertion that activists frame their activism according to crises on multiple scales. South Africa has a wide gap between rich and poor and many activists saw this affecting their activism, access to justice, and social inequality. Thus, these women human rights defenders connected their advocacy work with concerns of activists from other countries. 
Both research participants and collaborators explained how in South Africa, the issue of 'defending' rights was particularly interesting because the constitution of 1994 is one of the most progressive constitutions of the world, although these rights were still difficult to access. The Human Rights Commission still holds a strong political position in the country and there are authorities to which citizens can make claims on their rights. However, for many activists, defending rights reflected the challenges activists faced in their everyday work, which included lawyers accompanying human rights processes, psychologists and social workers consulting women victims of violence, and activists organising for Internet rights.

Some activists emphasised that both South Africa and Honduras had some of the highest incidents of violence against women worldwide. Much of the discrimination and impunity stems from corruption, weak policing, and a weak judicial system, which is why participants considered advocacy work in international spaces particularly important. In addition to advocating for human rights at international organisations such as the UN, the term enabled activists to build transnational alliances. This was particularly notable in a conversation with an activist from CALS. In September 2016, she had just returned from the AWID Forum, one of the largest international gatherings of women human rights defenders. She personally felt part of the transnational network of women human rights defenders but understood why the term was difficult to adopt in South Africa and many preferred the term 'women activists'. In her view, the term itself was the issue. Activists in Honduras may understand 'defensoras' differently than South African activists understand 'defenders' or the translation into ten other official languages by their respective activists - or there weren't equivalent words. It was therefore challenging for women in different communities to adopt an identity as human rights defenders. This reflects Okazawa-Rey's (2009) notion that language plays a crucial role in activism.

\section{Learning from multi-sited research: Reflections on methodology, outcomes and future research}

Human geographers underline how identities, interests and views are constructed through lived experiences on multiple scales (Nagar \& Ali 2003). In Honduras, activists experienced human rights violations during the protests and acknowledged they were defending their rights against the military and police violence. Therefore, activists had already identified themselves in a local context as human rights defenders during the protests in 2009. Since then, activists have also adopted the identity at international organisations such as the UN. In South Africa, activists translated the concept through transnational networks. They perceived 
it primarily as a tool to advocate internationally as well as to build transnational alliances with other activists - hence, activists' mobility was crucial for using the concept women human rights defenders. Others argued that many activists opposed international concepts and 'women human rights defenders' had therefore not spread as an identity locally. In addition, the concept was difficult to translate into local languages.

I argue first that conducting collaborative and participatory research at multiple sites helped break hierarchies and include multiple perspectives in the research process. It made us - the participants, research collaborators, and me - together critically view the concept and think about other ways to frame the same issues. Therefore, multi-sited research goes beyond mere self-reflection on positionality because it encourages us to include participants' and researchers' gaze beyond a single case study.

Second, the methodology raised new questions: In addition to explaining how the network of women human rights defenders emerged, it allowed to reflect on how, in which contexts and at what scales activists perceived and translated the term in Honduras and South Africa. As scholars have argued, activists worldwide have found new ways to respond to multilevel socioeconomic and political crises (Fraser 2013; Katz 2012). This study indicates the various ways that activists globally identify themselves as women human rights defenders. Conversations with research collaborators and activists demonstrated that "women human rights defenders' is not a homogeneous concept. A 'woman human rights defender' can refer to an indigenous woman who defends the environment, an urban feminist organising for reproductive rights, a woman advising victims of domestic abuse, or an internet-rights activist.

Third, this multi-sited approach shows that women's human rights framing can vary but still pursue the same goals - whether activists refer to women's activism, feminist activism or defending women's human rights. Thus, multi-sited research improves our understanding of transnational concepts that activists, decision-makers, and scholars in the international community often take for granted. Numerous studies have explored questions of representation and power in collaborative and participatory research projects. However, it is important to find evidence on how such research at multiple sites influences the way we conceptualise research as such.

Finally, the study shows that human rights concepts do have discursive power for feminists and other women activists in specific contexts. This geographic research, emphasising the importance of multiple research perspectives, can and should be extended to how activists perceive, conceptualise, and benefit from such frameworks. 


\section{Acknowledgments}

First, I want to thank Sheila Meintjes, Eddy Mazembo Mavungu, Ursula Scheidegger and other members of our Safeguarding Democracy project's first phase (2010-2013) who came up with the term "crossed gaze" (regard croisé). In addition, discussions during several years with project collaborators from the University of the Witwatersrand, University of Bern and the University of Basel significantly contributed to this research. I would particularly like to thank Doris Wastl-Walter, Elham Manea, Cynthia Kros, Michèle Amacker, Sophie Hirsig and Fatima Mukaddam for their inputs on earlier versions and presentations of this paper. Thank you also to the participants in Honduras and South Africa for sharing their views with me. Finally, I am grateful to the three anonymous reviewers for their valuable comments.

\section{References}

Alvarez S E 2008 Translating the global effects of transnational organising on local feminist discourses and practices in Latin America Meridians 1 29-67

Caretta M A and Riaño Y 2016 Feminist participatory methodologies in geography: creating spaces of inclusion Qualitative Research 163 1-9

Collins F L and Huang S 2012 Introduction to special section on migration methodologies: Emerging subjects, registers and spatialities of migration in Asia. Area $443270-73$

Crenshaw K 1991 Mapping the Margins: Intersectionality, identity politics, and violence against women of colour Stanford law review 436 1241-99

Demeritt D and Dyer S 2002 Dialogue, metaphors of dialogue and understandings of geography Area $343229-41$

Falzon, M A ed 2016 Multi-sited ethnography: theory, praxis and locality in contemporary research Ashgate Publishing, New York

Faria C and Mollett S 2016 Critical feminist reflexivity and the politics of whiteness in the 'field' Gender, Place \& Culture 23 1 79-93

Fisher K T 2015 Positionality, subjectivity and race in transnational and transcultural geographical research Gender, Place \& Culture 224 456-73 
Fraser N 2013 A triple Movement? Parsing the politics of crisis after Polanyi New Left Review $81119-32$

Hancock, A.-M. (2016). Intersectionality: An intellectual history. New York: Oxford University Press.

Haraway, D (1991). Simians, cyborgs, and women: The reinvention of women. New York: Routledge.

Hassim S Women's organisations and democracy in South Africa. Contesting Authority University of Wisconsin Press, Madison

IM Defensoras 2013 Policy and practice note. A Feminist alternative for the protection, selfcare, and safety of Women Human Rights Defenders in Mesoamerica Journal of Human Rights Practice 53 446-59

IM Defensoras 2015 Violence against Women Human Rights Defenders in Mesoamerica Report 2012-2014

Jaquette J S ed 2009 Feminist Agendas and Democracy in Latin America Duke University Press, Durham

Katz C 1992 All the world is staged: intellectuals and the projects of ethnography. Environment and Planning D Society and Space 105 495-510

Katz C 2012 Partners in Crime? Neoliberalism and the Production of New Political Subjectivities Antipode 227-235

Mama A 2011 What does it mean to do feminist research in African contexts? Feminist Review Conference 98(1), 4-20

Manea E 2016 Women and Shari'a Law. The Impact of Legal Pluralism in the UK I.B. Tauris, London

Marcus G 2009 Multi-sited Ethnography: Notes and Queries in Falzon M ed Multi-sited ethnography: Theory, praxis and locality in contemporary research 181-96. New York: Routledge 
Marcus G E 1995 Ethnography in the world system: The emergence of multi-sited ethnography Annual Review of Anthropology 24 95-117

Marston, S. A., Jones, J. P., \& Woodward, K. (2005). Human geography without scale. Transactions of the Institute of British Geographers, 30(4), 416-432

Massey D 1999 Philosophy and politics of spatiality: some considerations Geographische Zeitschrift 87 1-12

Meintjes, S. and Scheidegger, U. (2013) 'Challenges to Democracy: Looking with a South African Gaze on Democracy in Switzerland and a Swiss Gaze on Democracy in South Africa'. Conference Paper presented at the 5th European Conference on African Studies: African Dynamics in a Multipolar World, Lisbon, June 2013.

Mendoza B 2002 Transnational feminisms in question. Feminist Theory 3 3295-314

Merry S E 2006 Transnational human rights and local activism: Mapping the middle. American Anthropologist 108 138-51

Mohanty C T 2003 Feminism without borders: Decolonizing theory, practicing solidarity Duke University Press, Durham

Mohanty C T 2013 Transnational feminist crossings: On neoliberalism and radical critique. Signs $384967-91$

Mollett S. (2016). The power to plunder: Rethinking land grabbing in Latin America. Antipode 48 (2), 412-432

Monk J Manning P and Denman C 2003 Working together: feminist perspectives on collaborative research and action ACME: An International Journal for Critical Geographies 2 $191-106$

Nagar R 2014 Muddying Waters. Coauthoring Feminism across Scholarship and Activism University of Illinois, Champaign

Nagar R and Ali F 2003 Collaboration across borders: Moving beyond positionality. Singapore Journal of Tropical Geography 243 356-72 
Naples N A 2003 Feminism and Method: Ethnography, Discourse Analysis and Activist research Routledge, New York

Narayan U and Harding S 2000 Decentering the Center: Philosophy for a Multicultural Postcolonial and Feminist World Indiana University Press, Bloomington

Okazawa-Rey M 2009 Solidarity with Palestinian women: Notes from a Japanese black U.S. feminist in Sudbury J and Okazawa-Rey M eds Activist Scholarship. Antiracism, Feminism, and Social Change Paradigm Publishers Boulder 205-23

Pratt G 2002 Collaborating across Our Differences Gender, Place \& Culture 92 195-200

Pratt G Johnston C 2014 Filipina domestic workers, violent insecurity, testimonial theatre and transnational ambivalence Area 464 358-60

Raju S 2002 We are different, but can we talk? Gender, Place \& Culture 9 173-77

Schurr C and Segebart D 2012 Engaging with feminist postcolonial concerns through participatory action research and intersectionality Geographica Helvetica 67 147-54

Segebart D and Wastl-Walter D 2012 Multidirektionale Transfers. Internationalität in der Geschlechterforschung - eine Einführung Querelles. Jahrbuch für Frauen und Geschlechterforschung 16

Smith L T 2012 Decolonizing Methodologies Zed Books Ltd, New York

Staeheli L and Nagar R 2002 Feminists talking across worlds Gender, Place \& Culture 9 $167-72$

Sundberg J 2014 Decolonizing Posthumanist Geographies Cultural Geographies 211 33-47

Thayer M 2010 Translations and Refusals: Resignifying meanings as feminist political practice Feminist Studies $361200-30$

UN General Assembly (1998). Declaration on the Right and Responsibility of Individuals, Groups and Organs of Society to Promote and Protect Universally Recognized Human Rights and Fundamental Freedoms, 9 December 1998. A/RES/53/144. Retrieved from https://www.ohchr.org/Documents/Issues/Defenders/Declaration/declaration.pdf 
UNHRC 2012 Statement of the United Nations Special Rapporteur on the situation of human rights defenders, Margaret Sekaggya, on the conclusion of her official visit to Honduras. Geneva: UNHRC

UNHRC 2015 Human Rights Council Working Group on the Universal Periodic Review twenty-second session 4-15 May 2015 Honduras A/HRC/WG.6/22/HND/3 Geneva: UNHRC

De Vault M 1999 Liberating Method: Feminism and Social Research Temple University Press, Philadelphia

Walker M 2015 The productive and disruptive methodology of doing fieldwork at work Area $474473-78$ 